\title{
Socio-cultural beliefs influence feeding practices of mothers and their children in Grand Popo, Benin
}

\author{
Yrence Urielle Amoussou Lokossou', Ayuk Betrand Tambe ${ }^{1}$, Colette Azandjèmè ${ }^{2}$ and Xikombiso Mbhenyane ${ }^{1 *}$ (D)
}

\begin{abstract}
Background: Malnutrition is a major public health problem. It contributes to the high death rate among children in developing countries despite the various advocacies of institutions such as WHO and FAO and many other organisations. More research needs to be done in order to contribute to the achievement of the Sustainable Development Goals. The aim of this study was to explore socio-cultural practices and their influence on feeding practices of mothers and their children in Grand Popo, Benin.
\end{abstract}

Methods: A qualitative research methodology was used with an inductive approach. A pretested discussion guide was used to conduct focus group discussions with participants in their local language. Four focus group discussions were held in 4 villages located in both the rural and the semi-urban areas with each focus group comprising seven to eight participants. The study protocol was approved by the Health Research Ethics Committee of Stellenbosch University. Focus group discussions were recorded, transcribed and translated to English. The data was analysed following the Creswell data analysis steps.

Results: All the children were breastfed, and $56.1 \%$ of children under 6 months received breast milk exclusively. Children were introduced to family foods at 5 months with very low consumption of animal protein and fruits. Mothers and children had monotonous diets with high consumption of vegetables and maize-based meals. Food taboos, particularly during pregnancy, were revealed. Those cultural beliefs were still followed by some mothers, and food rich in nutrients were pushed aside.

Conclusions: There is a need for educational interventions to raise awareness of the negative impacts of some socio-cultural practices on the health of the mother and child.

Keywords: Socio-cultural, Feeding practices, Children and mothers, Benin

\section{Background}

Malnutrition continues to be a major health burden in developing countries. Globally, it is the most important risk factor for illness and death. Every country is facing a serious public health challenge relating to malnutrition [1]. According to the World Health Organization

\footnotetext{
* Correspondence: xgm@sun.ac.za

'Division Human Nutrition, Faculty of Medicine and Health Sciences, Stellenbosch University, PO Box 241, Cape Town 8000, South Africa Full list of author information is available at the end of the article
}

(WHO) statistics, nearly half of all deaths in children under the age of five are attributable to undernutrition [2]. Between 2000 and 2016, the prevalence of stunting globally declined from 32.7 to $22.9 \%$, and the number of children affected fell from 198.4 million to 154.8 million [3]. Progress is being made to eradicate malnutrition, but authorities remain rather unhurried while undernutrition continues to wreak havoc among children and adults who were overweight, and obesity is increasing. Many studies have been carried out on malnutrition,

C C The Author(s). 2021 Open Access This article is licensed under a Creative Commons Attribution 4.0 International License, which permits use, sharing, adaptation, distribution and reproduction in any medium or format, as long as you give appropriate credit to the original author(s) and the source, provide a link to the Creative Commons licence, and indicate if changes were made. The images or other third party material in this article are included in the article's Creative Commons licence, unless indicated otherwise in a credit line to the material. If material is not included in the article's Creative Commons licence and your intended use is not permitted by statutory regulation or exceeds the permitted use, you will need to obtain permission directly from the copyright holder. To view a copy of this licence, visit http://creativecommons.org/licenses/by/4.0/ The Creative Commons Public Domain Dedication waiver (http://creativecommons.org/publicdomain/zero/1.0/) applies to the data made available in this article, unless otherwise stated in a credit line to the data. 
and despite the various advocacies of institutions such as WHO, Food and Agriculture Organization (FAO) and many other organisations, more work needs to be done to achieve the Sustainable Development Goals (SDGs).

Poor nutrition in the first 1000 days of a child's life can also lead to stunted growth, which is irreversible and associated with impaired cognitive ability and reduced school and work performance [4]. Rapid growth during pregnancy, breastfeeding, and dietary diversification in the 1- to 3-year period lead to specific nutritional needs during each of these stages [5]. It is crucial to ensure access to optimal nutrition for each mother and child for the first 1000 days of a child's life. The period of pregnancy and lactation and the first 2 years of life is a special nutritional challenge for those in need of nutrition or with inappropriate feeding practices [6].

Exclusive breastfeeding is defined as the practice of only giving an infant breast milk for the first 6 months of life (no other food or water) and has the single largest potential impact on child mortality of any preventive intervention [7]. Early initiation and exclusive breastfeeding for 6 months provides essential, irreplaceable nutrition for a child's growth and development and therefore prevent stunting [8]. It serves as a child's immunisation, providing protection from respiratory infections [9], diarrhoeal diseases and other potentially lifethreatening ailments $[10,11]$. Exclusive breastfeeding has a protective effect against obesity and certain noncommunicable diseases later in life [9]. Globally, $40 \%$ of infants between 0 and 6 months old are exclusively breastfed [2]. Over 800,000 children's lives could be saved every year among children under 5 years if all children 0 to 23 months were optimally breastfed. Breastfeeding improves intelligence quotient (IQ) and school attendance and is associated with higher income in adult life [9]. According to the Demographic and Health Survey (DHS) in Benin, 94\% of children under 2 years of age were breastfed, but only $33 \%$ were breastfed exclusively until 6 months [12]. On 12 September 2011, the Republic of Benin joined the SUN Movement. At the time, Benin had established a multi-sectoral, multistakeholder platform, the National Council of Food and Nutrition under the office of the President. Benin also had a policy document, the Strategic Plan for Food and Nutrition Development which laid out both nutritionspecific and nutrition-sensitive approaches to improving nutrition $[6,12]$.

Young children need adequate dietary intake (through exclusive breastfeeding followed by quality complementary feeding) to support the rapid rate of growth that occurs in the first 2 years of life. Inadequate feeding and care practices often lead to a rapid decline in nutritional status after birth, and more prominently after 3 to 4 months of age (when other foods beyond just breast milk are typically introduced).

Different forms of taboos and cultural beliefs about food exist. They vary from one society to another and range from food for the adult and food fed to children. For example, snails and cane rat meat are taboo among pregnant women and eggs among children in Southeastern Nigeria [12]. Similarly, in rural Ethiopia, pregnant women avoid eating green leafy vegetables, yoghurt, cheese, sugarcane and green pepper as habitual in fear of obstetric complications associated with the delivery of a bigger infant [13]. A study conducted in the Gambia reported that taboos, customs and beliefs contribute to malnutrition among the Fula in different ways [14]. Another study in Kenya also observed that food taboos are delaying the progress in fighting undernutrition because of cultural beliefs [15]. These beliefs are thought to limit the intake of essential nutrients. Furthermore, a study conducted in Papua New Guinea has shown that many foods that are rich sources of protein have been enlisted as taboos for pregnant women. It is believed that because protein helps the body to grow, if a woman consumes a lot of protein in her pregnancy, then the baby will grow too big leading to complications during labour [16]. It is now believed that some of the food taboos on restrictions on what women could eat are rooted in the patriarchal philosophy of the past. It was hypothesised that there is a positive relationship between socio-demographic, nutritional status of children and mothers, dietary patterns and socio-cultural practices. Thus, the aim of this study was to explore socio-cultural practices and their influence on feeding practices of children and their mothers in Grand Popo, Benin. The nutritional status of the children and their mothers has been reported [17].

\section{Methods \\ Methodological design}

The study design was exploratory, descriptive and qualitative with an inductive approach [18]. This methodology eased a better understanding of the dietary sociocultural practices among mothers. The focus group technique was used to collect data.

\section{Study setting and population}

Benin is a French-speaking West African nation with an estimated population of 11.8 million inhabitants. The population of the community of Grand Popo is estimated at 57,636 inhabitants, 28,237 men and 29, 399 women, according to the national demography in 2013 [19]. The community of Grand Popo is in the southwest of the Mono Department. The Mono Division is one of the 12 divisions located in the southwest of Benin. It is 
bounded to the north by the communities of Athiemé, Comé and Houéyogbé; to the south by the Atlantic Ocean; to the south-west by the communes of Ouidah and Kpomassè; and to the west by the Republic of Togo.

The sample for this study was purposively recruited from participants of the related study from the same community which had 408 mother-child pairs from 24 villages. The children were under 5 years, and if the mother had more than one child, the youngest was preferred for the study. The inclusion criterion was parents living in the area for at least 6 months with children between 0 and 60 months, while the exclusion criteria were households not residing in the areas or those with no children in the 0 to 60 months age range.

Focus groups were held in 4 villages selected from the 24, with eight to ten participants. A common guideline for focus group research is to conduct at least two focus groups for each demographic stratum in the study [20,21]. For this research, four groups were deemed sufficient to be able to reach data saturation [22].

\section{Data collection procedure}

The four focus group discussions (FGD) were held between February and April 2019. The discussion groups comprised seven to eight participants gathered in the public square or under the tree. Focus groups were conducted to establish the socio-cultural practices that influence children's diets. The researcher welcomed the participants, asked each of them to introduce themselves and summarised the purpose of the discussion and informed the members that participation was voluntary. They were informed that the discussions were recorded, and confidentiality was assured to them. The researcher facilitated the focus group using the discussion guide which elaborated on specific topics identified to help manage the discussion. Themes were about healthy diet, breastfeeding, practice of exclusive breastfeeding, food usually given to a child in a day, foods necessary for child growth, first year feeding practices, care practices and feeding during illness, food distribution in the household (who is served first), foods taboos, restrictions during pregnancy and breastfeeding (women), foods eaten especially during pregnancy and lactation for mother and child good health, foods young children cannot eat and foods not eaten during illness. Two research assistants, who were students from the Department of Nutrition of the University of Abomey-Calavi, Benin, were selected to help the researcher with information recording. Assistants were observers during the discussions, who recorded and took notes. The researcher facilitated the sessions and allowed participants to express themselves freely.

\section{Trustworthiness and quality control}

Quality control of the focus group guide was assured by choosing guidelines for the discussion from instruments that have been validated in preceding studies [23, 24]. In addition, the guidelines for the FGD were tested in a pilot study in 2017 to assess if the questions were appropriate to be used in the study setting. The discussion guide consisted of six main themes of questions with probing questions that were used when needed. If a new probing question was added during a discussion and provided additional insights, it was then used during the next discussion. The discussion was conducted in the local language (Mina) using the French guideline, since most mothers did not understand French nor English. Two research assistants assisted with the recording of information and the capturing of the socio-demographic characteristics of the mothers. The recording was in the local language while the notes were done in French and English.

\section{Ethical considerations}

Ethical clearance was obtained from the Health Research Ethics Committee of Stellenbosch University (Reference no: S16/10/211). The study proposal was also submitted, and administrative authorisation obtained from the Departmental of Health of Mono-Couffo (Benin) to conduct the survey in the region. The recruitment of participants started with the researcher and assistants' introduction to the chief of the village, where they explained the purpose of the study and sought permission. The chief helped the team to contact and recruit households. Prior to the interview, the mothers were informed of the goal of the study in the local Mina language before they were invited to participate in the study and informed consent obtained. The mothers were advised that their participation was voluntary and that they could withdraw at any time point without any explanation. Confidentiality was assured to them. The mothers of the children who agreed to participate in the study were presented with the consent form for signing.

\section{Data analysis}

The focus group data interviews recorded were transcribed and translated from Mina and French to English. The data collected was classified and organised into themes before generalisations were made. The analysis was done according to Creswell's [25] five steps of qualitative data analysis. The data was first grouped into 13 discussion topics (used as codes and focus groupings). After responses were analysed and synthesised in terms of nutritional content and similarities, they were categorised according to the following themes relevant for feeding of a young child while keeping the focus groups: 
(i) healthy diet, (ii) exclusive breastfeeding, (iii) first year diet and (iv) growth foods.

\section{Results}

\section{Socio-demographic characteristics}

Four focus group discussions were carried out with an average of 8 mothers per focus group (see Table 1 with focus group information).

A total of 31 mothers between 19 and 60 years selected in both rural and semi-urban areas in Benin participated in the study. These 31 mothers were part of the sample of 408 mothers whose demographic data is reported elsewhere [17]. The majority $(93.1 \%)$ of the mothers were married or living with the partner and living in a monogamous household. Most of the mothers had no formal education $(40.2 \%)$ or just the primary level of education (36\%). A greater proportion of the households used paraffin oil for lighting and firewood for cooking meals. They got drinking water from manual pumps (39.7\%) or wells $(44.4 \%)$. Few households still used surface water (rivers, ponds or lakes; 5.1\%). Regarding sanitation, most (77\%) do not have access to toilet facilities.

Few mothers were head of household, and most of them were divorced or widowed. A greater proportion of mothers had income from small shops or depended on the husband. In most households where the participants lived, men decided how to spend money and purchase food, and sometimes, partners decided together. Regarding the economic characteristics of households, $91.7 \%$ of households had a monthly income of US\$60 and spent on average US\$24 + US\$11.2 on food [17].

Various studies have indicated that low household income has a direct impact on the nutritional status of children [26-28]. Choosing to buy foods depends on the father; there is thus a risk of malnutrition since women can supply more nutritious food to the children when they control the variety when purchasing food. Most of the households lived in one room, and most of the time, it is a family house.

\section{Focus groups discussions}

Through the focus groups conducted, mothers' knowledge about nutrition, care practices, food distribution within the household and food taboos were discussed (see Tables 2, 3, 4 and 5). During focus group

Table 1 Focus group characteristics

\begin{tabular}{lll}
\hline Groups & Number & Age range \\
\hline One & 8 & 20 to 60 \\
Two & 7 & 19 to 40 \\
Three & 8 & 20 to 40 \\
Four & 8 & 22 to 40 \\
Total & 31 & \\
\hline
\end{tabular}

discussions, the mothers highlighted food taboos practised in their communities, as well as some perceptions and misconceptions about child feeding. Several reasons were given to explain why they avoided certain foods during pregnancy and refrained from feeding to their children. Their verbatim responses are organised in Tables 2, 3, 4 and 5. Their responses are grouped according to themes: exclusive breastfeeding, healthy diet, first year diet, growth foods, care practices, food distribution and food taboos. The interpretation of the FGDs is summarised below.

\section{Exclusive breastfeeding}

Most participants seem to have breastfed their children for up to 18 months. Most said they gave water to the child before 6 months, thus not truly exclusive breastfeeding. Environment, time and misconceptions, and beliefs were limits identified to influence exclusive breastfeeding practice.

\section{Healthy diet}

Starch and legumes were cited by most groups as part of a healthy diet. The feeling of eating food you appreciate and that one assumes nutritious form part of a healthy diet.

\section{First year diet}

Dietary practices during the first year revealed that most mothers cited maize porridge as the first food followed by other foods or what the family eat. Their responses confirm the types of foods identified as regularly consumed in other studies.

\section{Growth foods}

The participants identified protein sources especially fish, legumes, fruits and vegetables as growth foods. They knew that common traditional foods could affect the growth of their children.

\section{Care practices}

Most mothers said they treat their children at home using tablets or herbal tea and only go to the hospital when the condition worsens. They also said that they get or listen to the advice from the children's grandmothers on how to care for their children. They primarily give maize porridge to the child during sickness, and when he/she gets better, normal family food is given.

\section{Food distribution}

Most mothers said children are served first, but the men receive the 'best' part of the meals, and in some households, the men are served first, or their portions are removed before serving the children and other members of the household. 
Table 2 Focus groups discussion concerning a healthy diet, exclusive breastfeeding

\begin{tabular}{|c|c|c|c|c|c|}
\hline & Focus group 1 & Focus group 2 & Focus group 3 & Focus group 4 & Interpretation \\
\hline $\begin{array}{l}\text { Exclusive } \\
\text { breastfeeding }\end{array}$ & $\begin{array}{l}\text { - One mother did it. But } \\
\text { it was difficult because } \\
\text { of environment. Most } \\
\text { of mothers give water } \\
\text { or porridge to children } \\
\text { and old women don't } \\
\text { allow young to do it. } \\
\text { - Nurses taught them } \\
\text { about it but they think } \\
\text { baby is thirsty and } \\
\text { need water even the } \\
\text { same day of birth. } \\
\text { - To do it you need to } \\
\text { be strong in your } \\
\text { mind and must have } \\
\text { milk in your breast. }\end{array}$ & $\begin{array}{l}\text { - What we eat is found } \\
\text { in our milk, so the } \\
\text { breastfeeding is good. } \\
\text { All we breastfeed at } \\
\text { least until } 18 \text { months. } \\
\text { - I heard that milk } \\
\text { contains lot of water } \\
\text { for example } 10 \ell \text { of milk } \\
\text { contains } 9 l \text { of water } \\
\text { and } 1 \ell \text { of vitamins so if } \\
\text { you give water to the } \\
\text { child, he will not have } \\
\text { many vitamins } \\
\text { - Milk alone is not } \\
\text { enough for the child, } \\
\text { so I give him water. } \\
\text { - When we go to the } \\
\text { hospital, we received } \\
\text { advice, but we all give } \\
\text { water to children. They } \\
\text { are thirsty and cry to } \\
\text { ask for it. If you are } \\
\text { with your grandmother, } \\
\text { she will say to give it. } \\
\text { - Some of mothers give } \\
\text { up at } 18 \text { months others } \\
24 \text { months, depend on } \\
\text { each mother's feelings }\end{array}$ & $\begin{array}{l}\text { - Breastfeeding is } \\
\text { essential. Milk is for } \\
\text { child. } \\
\text { - Give up at } 18 \text { months } \\
\text { or } 2 \text { and a half years. } \\
\text { - My first child had drunk } \\
\text { formula because I had } \\
\text { a problem with my } \\
\text { breast but the second } \\
\text { one drank my milk. } \\
\text { - No exclusive } \\
\text { breastfeeding because } \\
\text { child is thirsty, he } \\
\text { needs water. It's hot it's } \\
\text { not easy for an adult } \\
\text { what to say about child } \\
\text { who cannot tell you if } \\
\text { he is not fine. He cries } \\
\text { and we give water. } \\
\text { - They said breastfeeding } \\
\text { exclusively is good but } \\
\text { needs of the child are } \\
\text { different. } \\
\text { - Give water at } 3 \text { months. } \\
\text { - For myself I wanted to } \\
\text { give her milk alone, but } \\
\text { his grandmother gave } \\
\text { him. When I refused, } \\
\text { she took him herself to } \\
\text { give it to him. She did } \\
\text { it the same day at her } \\
\text { birth. Heat water to } \\
\text { sterilise it and give it. }\end{array}$ & $\begin{array}{l}\text { - Breast milk is good for } \\
\text { children. It develops } \\
\text { strength and intellect. } \\
\text { They take up to } 2 \text { years. } \\
\text { It's just knowledge. } \\
\text { Doctors have taught us } \\
\text { to give milk to children } \\
\text { without water until } 6 \\
\text { months. } \\
\text { - Milk make children } \\
\text { thirsty so we give } \\
\text { water. } \\
\text { - Breastfed exclusively up } \\
\text { to } 6 \text { months after I } \\
\text { make him imported } \\
\text { porridge flour. But this } \\
\text { child refuses porridge } \\
\text { he prefers dough, rice. } \\
\text { - Not exclusively } \\
\text { breastfed my child. } \\
\text { Weaning at } 9 \text { months } \\
\text { with maize roasted } \\
\text { flour. }\end{array}$ & $\begin{array}{l}\text { Most participants seem } \\
\text { to have breastfed their } \\
\text { children for up to } 18 \\
\text { months. Most said they } \\
\text { gave water to the child } \\
\text { before } 6 \text { months, thus } \\
\text { not truly exclusive } \\
\text { breastfeeding. } \\
\text { Environment, time and } \\
\text { misconceptions, and } \\
\text { beliefs are limits for } \\
\text { exclusive breastfeeding } \\
\text { practice. }\end{array}$ \\
\hline Healthy diet & $\begin{array}{l}\text { - See by the physical } \\
\text { health of the } \\
\text { individual } \\
\text { - Eating spaghetti, maize } \\
\text { paste, fresh fish sauce, } \\
\text { vegetables, egoussi } \\
\text { sauce (squash seeds) } \\
\text { - Food consumed } \\
\text { quality } \\
\text { - When you are fine, } \\
\text { you eat well } \\
\text { - Cook food rich in } \\
\text { nutrients }\end{array}$ & $\begin{array}{l}\text { - Maize foods, rice, } \\
\text { cowpea, egg, peanut } \\
\text { - Maize stiff porridge has } \\
\text { lots of vitamins. We eat } \\
\text { at least once a day. } \\
\text { - Eating food that make } \\
\text { us feeling good. }\end{array}$ & $\begin{array}{l}\text { - Eating paste and bitter } \\
\text { leaves sauce, palm nut } \\
\text { sauce, wild basil sauce, } \\
\text { gari } \\
\text { - What you eat, and you } \\
\text { feel good that is eating } \\
\text { well } \\
\text { - A food that you } \\
\text { prepare carefully, eat } \\
\text { and that's give you } \\
\text { nutrients and good } \\
\text { health. Those nutrients } \\
\text { your child receives } \\
\text { through the breastmilk } \\
\text { is a good diet. }\end{array}$ & $\begin{array}{l}\text { - Eat good food. } \\
\text { Cowpea, potato, } \\
\text { moringa it is good for } \\
\text { children's health }\end{array}$ & $\begin{array}{l}\text { Starch and legumes } \\
\text { were cited by most } \\
\text { groups as part of a } \\
\text { healthy diet. The feeling } \\
\text { of eating food you } \\
\text { appreciate and that one } \\
\text { assumes nutritious form } \\
\text { part of a healthy diet. }\end{array}$ \\
\hline
\end{tabular}

\section{Food taboos}

Catfish, crabs, eggs, pork and African eggplant were cited by many as taboo foods, especially for pregnant women. Some foods which are rich in nutrients are forgotten because of cultural or religious beliefs.

\section{Discussions}

\section{Mothers' knowledge and perceptions about nutrition}

This section covers responses on the themes of exclusive breastfeeding, first year diet, healthy diet and growth foods. The verbatim responses are summarised in Tables 2 and 3. The results showed that mothers had limited knowledge about nutrition. For the majority who did not go to school, the source of information remains the elders and the cycle is perpetuated. Despite some nutrition education sessions during hospital care visits, mothers do not apply the knowledge learnt and recommendations proposed by the health workers, either because they say they do not have time or because their family environment does not allow for it. For example, in focus group 3, the mother had the will to exclusively breastfeed her child, but the mother-in-law refused and gave water to the child from the first day. She said: 'For me, I wanted to give him milk only, but his grandmother gave him water. When I refused, she took him herself to give it to him. She did this the same day of his birth'. The belief that breast milk alone is not sufficient in meeting the nutritional needs of infants remained 
Table 3 Focus group discussion concerning the diet of the child's first year and growth foods

\begin{tabular}{|c|c|c|c|c|c|}
\hline & Focus group 1 & Focus group 2 & Focus group 3 & Focus group 4 & Interpretation \\
\hline $\begin{array}{l}\text { First } \\
\text { year } \\
\text { diet }\end{array}$ & $\begin{array}{l}\text { - Infant formula milk. } \\
\text { - First food to give to child } \\
\text { after milk should be } \\
\text { cereals. } \\
\text { - At } 3 \text { months, some start } \\
\text { giving simple maize } \\
\text { porridge or maize } \\
\text { roasted porridge. } \\
\text { - Others make flour with } \\
\text { maize, soybean (roasted), } \\
\text { biscuit, small dried fish } \\
\text { (dowevi, tcheke) and } \\
\text { grind it in small portion } \\
\text { to see if infant like it. } \\
\text { - Use also sorghum and } \\
\text { maize, do not like } \\
\text { soybean because it is not } \\
\text { good for all children. } \\
\text { - Can buy the porridge in } \\
\text { the supermarkets. } \\
\text { - Rice and macaroni. }\end{array}$ & $\begin{array}{l}\text { - We feed child when we } \\
\text { eat giving him portion by } \\
\text { portion. } \\
\text { - We start with maize } \\
\text { porridge (flour and water) } \\
\text { maize dough and jute } \\
\text { sauce, macaroni to give it } \\
\text { the taste of family meals } \\
\text { and after it will be used. } \\
\text { - You can give him egg } \\
\text { sometimes or donut when } \\
\text { he's on the back, so he } \\
\text { sucks or eats. } \\
\text { - It depends on the child } \\
\text { and how he accepts } \\
\text { eating. }\end{array}$ & $\begin{array}{l}\text { - At } 6 \text { or } 7 \text { months, I } \\
\text { start with porridge. } \\
\text { - Eat the usual foods. } \\
\text { - No time to give food } \\
\text { especially. He will be } \\
\text { taken off breast and } \\
\text { when I want to eat, I } \\
\text { also give him if he } \\
\text { could eat. } \\
\text { - Maize porridge, paste } \\
\text { and jute sauce, rice, } \\
\text { macaroni, cowpea no } \\
\text { egg frequently it is } \\
\text { when we have } \\
\text { money, we buy it. } \\
\text { - Maize porridge with } \\
\text { maize flour and water. } \\
\text { - Porridge and cow } \\
\text { milk. I no longer give } \\
\text { egg because I cannot } \\
\text { afford to buy. We give } \\
\text { fish and meat if } \\
\text { present in the sauce. }\end{array}$ & $\begin{array}{l}\text { - Macaroni, paste and } \\
\text { jute sauce, rice, } \\
\text { cowpea. } \\
\text { - Child can eat cowpea } \\
\text { at } 10 \text { months. } \\
\text { - He couldn't. He is too } \\
\text { young for that. } \\
\text { - He could. Just } \\
\text { prepare it well and } \\
\text { crush. Give meat and } \\
\text { fish occasionally. Eat } \\
\text { eggs regularly, at } \\
\text { least three times a } \\
\text { week. }\end{array}$ & $\begin{array}{l}\text { Most mothers cited maize } \\
\text { porridge as the first food } \\
\text { followed by other foods or } \\
\text { what the family eat. Their } \\
\text { responses confirm the types } \\
\text { of foods identified as } \\
\text { regularly consumed. }\end{array}$ \\
\hline $\begin{array}{l}\text { Growth } \\
\text { foods }\end{array}$ & $\begin{array}{l}\text { - Meat, fish, cowpea not } \\
\text { too much oil, milk, eggs. } \\
\text { - If it is only gari and fresh } \\
\text { fish you will give to your } \\
\text { child, he won't grow. } \\
\text { - Can also prepare } \\
\text { vegetable sauce (African } \\
\text { eggplant sauce) and put } \\
\text { moringa in all foods. }\end{array}$ & $\begin{array}{l}\text { - Cowpea, tilapia, avocado, } \\
\text { banana, orange, fruits, } \\
\text { vegetables } \\
\text { - Just dough we give to our } \\
\text { children, and they grow } \\
\text { up well. } \\
\text { - We do not have processed } \\
\text { milk for children. We only } \\
\text { have our foods here. } \\
\text { When one gives small fish, } \\
\text { someone thinks that it is } \\
\text { poverty. }\end{array}$ & $\begin{array}{l}\text { - Paste, cowpea, } \\
\text { macaroni, rice, okra } \\
\text { and jute sauce, } \\
\text { orange, fruit, banana, } \\
\text { pineapple. } \\
\text { - Pineapple is not good } \\
\text { for kids it makes you } \\
\text { lose weight is better } \\
\text { for adults. }\end{array}$ & $\begin{array}{l}\text { - Fish, vegetables, } \\
\text { paste, jute sauce and } \\
\text { palm nut sauce }\end{array}$ & $\begin{array}{l}\text { The participants identified } \\
\text { protein sources especially } \\
\text { fish, legumes, fruits and } \\
\text { vegetables as growth foods. } \\
\text { They know that common } \\
\text { traditional foods can affect } \\
\text { growth in their children. }\end{array}$ \\
\hline
\end{tabular}

persistent and as soon as the child cried, he received water. One of the mothers said: 'No exclusive breastfeeding because child is thirsty he needs water. It's hot it's not easy for an adult what about a child who cannot tell you if he is not fine. He cries, and we give water'. Another one said: 'Babies are thirsty and cry to ask for water. If you are with your grandmother she will say give it'. The findings indicate that mothers are sometimes negatively influenced by significant grandmothers and others as to how to practise breastfeeding [29]. Most mothers seem to have breastfed their children for up to 18 months, according to the information provided during the discussions. However, most revealed that they gave water to the child before 6 months, thus not truly exclusive breastfeeding according to the WHO definition [30]. Environment, time and misconceptions, and beliefs are determinants for exclusive breastfeeding practice that were distilled from the conversations (Table 2). Our findings are supported by other studies which showed that the practice of exclusive breastfeeding and early breastfeeding does not seem to be limited by mothers' knowledge but by socio-cultural representations in certain societies. In Senegal, $42 \%$ of children received water before 6 months [31]. In South Africa, Seonandan and Mckerrow [32] showed in their review on infant and young child feeding practices in a hospital and some homes in KwaZulu-Natal Midlands that $76 \%$ of infants were ever exclusively breastfed with just $36 \%$ being exclusively breastfed beyond 3 months. Many children receive other fluids other than breast milk even before 1 month. One study in Western Cape showed that $90 \%$ of the mothers had introduced water, and $83 \%$ of them did it before the age of 1 month [33]. There is a void between recommendations and practices, and findings from this study point to socio-cultural determinants.

Social norms have a great impact on the quality of care provided to children by their mothers. There is a saying in West Africa that the whole family is responsible for supporting the child while growing up. The first year of a child's life is a delicate time that all mothers recognise. They introduce the child to adult food from as early as 3 months, or later, 5 or 6 months. On the topic of first year diet, most mothers cited maize porridge as the first food followed by other foods or what the family eat (Table 3). Their responses confirm the types of foods identified as regularly consumed. These foods included 
Table 4 Focus groups discussion concerning care practices and food distribution

\begin{tabular}{|c|c|c|c|c|c|}
\hline & $\begin{array}{l}\text { Focus } \\
\text { group } 1\end{array}$ & Focus group 2 & Focus group 3 & Focus group 4 & Interpretation \\
\hline $\begin{array}{l}\text { Care } \\
\text { practices }\end{array}$ & $\begin{array}{l}\text { - No special } \\
\text { food. } \\
\text { - Porridge } \\
\text { most of } \\
\text { the time. } \\
\text { - Treatment } \\
\text { at home } \\
\text { until } \\
\text { situation } \\
\text { become } \\
\text { worse. } \\
\text { - Use herbal } \\
\text { tea. } \\
\text { - Tablets. }\end{array}$ & $\begin{array}{l}\text { - If you have money you can } \\
\text { go to the hospital otherwise } \\
\text { you start treatment at home } \\
\text { first with herbal teas or go to } \\
\text { the healers. } \\
\text { - It is more often treated at } \\
\text { home first. } \\
\text { - When it takes too long time } \\
\text { for healing we go to hospital. } \\
\text { - We give the usual food but } \\
\text { more often porridge because } \\
\text { at this moment child don't } \\
\text { want to eat. We give him } \\
\text { food if he doesn't like we try } \\
\text { other things. } \\
\text { - If it is the measles, we don't } \\
\text { give peanut. He does not } \\
\text { wear clothes. }\end{array}$ & $\begin{array}{l}\text { - Give mostly porridge, and } \\
\text { some others like rice, paste } \\
\text { if he likes. } \\
\text { - We treat at home first, } \\
\text { hospital is expensive. Go } \\
\text { there when it is very } \\
\text { serious and has worsened. } \\
\text { - We give tablets we have at } \\
\text { home. } \\
\text { - We prepare herbal teas. } \\
\text { Grandmothers show us } \\
\text { leaves and we prepare. We } \\
\text { give as drink or wash them } \\
\text { with. The fever goes off } \\
\text { quickly. }\end{array}$ & $\begin{array}{l}\text { - We treat at home first } \\
\text { we prepare herbal tea } \\
\text { if after three days he } \\
\text { is still sick we go to } \\
\text { the hospital. } \\
\text { - He eats usual food } \\
\text { and what he likes. } \\
\text { When they are sick, } \\
\text { they don't take foods } \\
\text { too fat. It is not good. } \\
\text { - When they cough or } \\
\text { have digestive } \\
\text { problems, they cannot } \\
\text { eat okra. }\end{array}$ & $\begin{array}{l}\text { Most mothers said they treat } \\
\text { their children at home using } \\
\text { tablets or herbal tea and only } \\
\text { go to the hospital when the } \\
\text { condition worsens. They also } \\
\text { said that they get or listen to } \\
\text { the advice from the children's } \\
\text { grandmothers on how to care } \\
\text { for their children. They } \\
\text { primarily give maize porridge } \\
\text { to the child during sickness } \\
\text { and when he/she gets better, } \\
\text { normal family food is given. }\end{array}$ \\
\hline $\begin{array}{l}\text { Food } \\
\text { distribution }\end{array}$ & $\begin{array}{l}\text { - Children } \\
\text { received } \\
\text { first and } \\
\text { then men } \\
\text { are served. } \\
\text { - As soon as } \\
\text { you finish } \\
\text { preparing } \\
\text { you serve } \\
\text { them. }\end{array}$ & $\begin{array}{l}\text { - Children are served first } \\
\text { immediately you finish } \\
\text { cooking. } \\
\text { - Fathers are outside they may } \\
\text { have found something to eat } \\
\text { outside, and child would be } \\
\text { fasting at home? Children are } \\
\text { served first. } \\
\text { - They are served first but the } \\
\text { large portions of meat or fish } \\
\text { are reserved to fathers. }\end{array}$ & $\begin{array}{l}\text { - Dad is served first. Dad's } \\
\text { portion is first removed } \\
\text { after cooking. } \\
\text { - It is children who is served } \\
\text { first. They are hungry and } \\
\text { need more food than } \\
\text { adults. But it's for dad the } \\
\text { best part, the big fish/ } \\
\text { meat. } \\
\text { - Serve my children first after } \\
\text { their father and me. }\end{array}$ & $\begin{array}{l}\text { - Children are served } \\
\text { first. } \\
\text { - Children are served } \\
\text { first and after men are } \\
\text { served but the good } \\
\text { portion of fish or } \\
\text { meat is reserved to } \\
\text { the father. }\end{array}$ & $\begin{array}{l}\text { Most mothers said children are } \\
\text { served first, but the men } \\
\text { receive the 'best' part of the } \\
\text { meals, and in some } \\
\text { households, the men are } \\
\text { served first, or their portions } \\
\text { are removed before serving } \\
\text { the children and other } \\
\text { members of the household. }\end{array}$ \\
\hline
\end{tabular}

cereal porridge, which is mostly derived from maize. A simple corn meal is given to the child several times a day, in addition to breast milk. This porridge is low in protein and fat and the child would therefore require additional sources of these nutrients. A South African study has recorded several dietary deficits and a rising trend in the consumption of inappropriate nutritionally poor food during the first year [34]. Budree et al. [35] dedicated a high daily consumption of processed meat (56\%) and inappropriate foods such as fruit juice (82\%), soft drinks (54\%) and refined sugary foods (51\%) at 1 year of age. In another study done in Benin [36] cereal porridges which were unenriched were recorded as complementary foods given to children over 6 months and low consumption of fruits and eggs. Some affordable porridges for complementary feeding have been formulated to fulfil the nutritional needs of children from 6 months and older [34, 37]. A mother from focus group one stated that: 'Others make flour with maize, soybean (roasted), biscuit, small dried fish (dowevi, tcheke) and grind it in small portion to see if infant like it'. In focus group 2, one said 'We start with maize porridge (flour and water), maize dough jute sauce and macaroni to give the child the taste of family meals and after that the child will be used to the taste'. Studies in West Africa have shown that the diet of many households is composed of cereals, roots, tubers and root products, legumes and nuts, eggs, fish, vegetables and oil [37, 38]. Zeba et al. described dietary patterns in Ouagadougou' adults in Burkina Faso as high in local cereals, legumes and traditional green leafy vegetables [38] while Frank et al. [39] characterised the urban Ghana dietary pattern as high intakes of plantain, green leafy vegetables, beans, egg, fish, maize, palm oil, okra and fruits. Despite these practices for adults, mothers tend to give mostly Owo (stiff porridge) accompanied by local vegetable soup to the children who are on the family diet. Their diet is in most cases totally lacking in animal protein and fruit sources. Lack of funds and cultural believes limit the consumption of animal protein. Some mothers in focus group four said 'Child can eat cowpea (vegetable) and jute sauce at 10 months' another contradicted by saying 'He couldn't. He is too young for that' and another backed the first statement by saying 'He could. Just prepare it well and crush'. This is an indication that mothers have different perceptions and knowledge on what and how to prepare foods to give to the infant. On protein foods, one mother said 'Give meat and fish occasionally. Eat eggs regularly, at least three times a week'. The main source of animal protein in Grand Popo, Benin, is fish. This is understandable considering that it is a fishing community, and fish is available permanently in the households. In low-income countries, meat and milk products are often lacking in the diets of children. 
Table 5 Focus groups discussion concerning food taboos

\begin{tabular}{|c|c|c|c|c|c|}
\hline & Focus group 1 & Focus group 2 & Focus group 3 & Focus group 4 & \\
\hline Taboos & $\begin{array}{l}\text { - Our community does not } \\
\text { eat crabs, catfish that } \\
\text { families do not take. } \\
\text { There are family totems. } \\
\text { - The egg is not good } \\
\text { when you are pregnant } \\
\text { because you can quickly } \\
\text { give birth. } \\
\text { - When you breastfeed, } \\
\text { you do not eat African } \\
\text { eggplant, mango. They } \\
\text { give digestive problems.- } \\
\text { Don't give eggs to child } \\
\text { frequently. When you } \\
\text { have sometimes you can } \\
\text { give him if not it is not } \\
\text { possible because too } \\
\text { expensive. } \\
\text { The reason you have } \\
\text { poultry is for herd } \\
\text { increasing and sell it after } \\
\text { chicken. }\end{array}$ & $\begin{array}{l}\text { - Not everyone has } \\
\text { taboos. } \\
\text { - If I eat something and I } \\
\text { do not digest well, I do } \\
\text { not eat anymore. I don't } \\
\text { have taboos, do not eat } \\
\text { catfish. } \\
\text { - Do not eat catfish we do } \\
\text { not eat pork, dog, cat, } \\
\text { snake meat in my family } \\
\text { but I eat as soon as I } \\
\text { find. } \\
\text { - When we are pregnant, } \\
\text { we do not eat cane rat } \\
\text { (giant rats). } \\
\text { - We do not eat wild } \\
\text { meat, so children do not } \\
\text { become violent and } \\
\text { behave like a wild } \\
\text { animal. } \\
\text { - We do not eat local eggs } \\
\text { because you can have a } \\
\text { dead child because they } \\
\text { will not be glad that you } \\
\text { take his progeny. We can } \\
\text { eat imported eggs. Also, } \\
\text { kids can break things like } \\
\text { hen so it's best not to } \\
\text { eat them. } \\
\text { - We drink maize porridge } \\
\text { and dough to have lot of } \\
\text { milk. }\end{array}$ & $\begin{array}{l}\text { - Do not eat African } \\
\text { eggplant sauce that } \\
\text { gives digestive trouble } \\
\text { and diarrhoea. } \\
\text { - No eggs during } \\
\text { pregnancy. We can eat } \\
\text { but whole, we couldn't } \\
\text { share with someone else. } \\
\text { - A pregnant woman } \\
\text { should not prepare eggs } \\
\text { and give to someone. } \\
\text { She must cook for } \\
\text { herself and when she } \\
\text { removes the shell it } \\
\text { should not have any hurt } \\
\text { otherwise, she should } \\
\text { not eat because she } \\
\text { might have birth } \\
\text { complications. } \\
\text { - Pork is taboo for Muslims } \\
\text { and some families. } \\
\text { - Dog, cat, catfish, jute } \\
\text { sauce with palm oil. } \\
\text { There are no } \\
\text { explanations, we got it } \\
\text { from ancestors. } \\
\text { - No taboos only dog and } \\
\text { pork meat if not I eat } \\
\text { everything. But when } \\
\text { pregnant I do not like } \\
\text { anything. }\end{array}$ & $\begin{array}{l}\text { - Pork and dog are my } \\
\text { family totem. } \\
\text { - Sheep. } \\
\text { - Varanus, crab, anyone } \\
\text { in this community } \\
\text { don't eat catfish. } \\
\text { - Pregnant I do not eat } \\
\text { fish it gives me nausea } \\
\text { just the paste and chilli. } \\
\text { - Pregnant I eat } \\
\text { everything. It is said } \\
\text { that we should not eat } \\
\text { eggs to avoid birth } \\
\text { complications. } \\
\text { - When we are } \\
\text { breastfeeding, it is } \\
\text { recommended to eat } \\
\text { maize dough, African } \\
\text { eggplant, Bitter leaf, } \\
\text { maize fermented } \\
\text { porridge. } \\
\text { - For some, they think if } \\
\text { you give rice or } \\
\text { cowpea to child, he will } \\
\text { have digestive } \\
\text { problems, but it } \\
\text { depends on what you } \\
\text { teach to your child. } \\
\text { - When breastfeeding, } \\
\text { we do not eat banana, } \\
\text { mango, papaya to } \\
\text { avoid colic in children. } \\
\text { - We eat a lot of } \\
\text { moringa. We were } \\
\text { visited by people who } \\
\text { taught us that it is } \\
\text { good for children. }\end{array}$ & $\begin{array}{l}\text { Catfish, crabs, eggs, pork } \\
\text { and African eggplant } \\
\text { were cited by many as } \\
\text { taboo foods, especially for } \\
\text { pregnant women. Some } \\
\text { foods which are rich in } \\
\text { nutrients are forgotten } \\
\text { because of cultural or } \\
\text { religious beliefs. }\end{array}$ \\
\hline
\end{tabular}

Yet, the benefits of their consumption especially meat has been shown that it improved growth indicators, micronutrient status and cognitive performance [40]. The low consumption of meat can be explained by household income, accessibility, religious and cultural beliefs as seen in this study. Meat consumption is just occasional at events or parties in this study.

In addition, the consumption of fruits was limited in the present study, no mother mentions fruit or fruit juice as foods given during the first year. Several national and sub-national surveys have demonstrated the low consumption of fruit and vegetables in West Africa [41, 42]. Income, non-availability, nonaffordability and access determine the consumption of fruit and vegetables [43].

Concerning a healthy diet, one of the mothers said that: 'Healthy diet is seen by the physical health of the individual'. Another one said that: 'Eating imported/ processed foods and animal source foods'. Starch, legumes and vegetables such as cowpea, moringa and squash seeds were cited by most groups as part of a healthy diet (Table 2). Some also named food rich in nutrients and some mentioned vitamins. Their perceptions were that the feeling of eating food you appreciate and that one assumes nutritious form part of a healthy diet. One mother said, 'What you eat, and you feel good that is eating well'. With regard to growth foods (Table 3), the participants identified protein sources especially fish, legumes, fruits and vegetables as growth foods. They know that common traditional foods can affect the growth of their children. One mother said, 'Can also prepare vegetable sauce (African eggplant sauce) and put moringa in all foods'.

\section{Socio-cultural perceptions on child care practices}

Poor child feeding and care practices are associated with poor child nutritional status [44]. When a child is ill, the first action of the mother is to treat him/her at home with traditional medicine. They go to the hospital only when the child's condition worsens, after at least 3 days. As this mother from focus group 3 said: "We treat at home first, hospital is expensive, and we go there when it is very serious and has worsened' (see Table 4 for detailed responses). Most mothers said they treat their 
children at home using tablets or herbal tea and only go to the hospital when the condition worsens. They also said that they get or listen to the advice from the children's grandmothers on how to care for their children. They said 'We prepare herbal teas. Grandmothers show us leaves and we prepare. We give as drink or wash them with. The fever goes off quickly'. They primarily give maize porridge to the child during sickness, and when he/she gets better, normal family food is given; their perception of care is linked with feeding the child. Care is comprehensive in that it includes custodial care, such as, supervision, food, shelter and other physical necessities; it goes beyond these to include activities that encourage and aid learning responsible for children's health, social and psychological needs [45]. Child care supports a child's emotional, social, intellectual and physical well-being. The discussions in the focus groups only focused on food as part of care when they were probed. This is worrisome if mothers are not aware of their role in child development comprehensively.

\section{Decision-making and food distribution within households}

The way in which food is distributed in the household influences the nutritional status of a child. When distributing meals, especially fish, adults (often the father) are often favoured with the best part [46]. A mother from focus group 4 said: 'Children are served first and after men are served but the good portion of fish or meat is reserved for the father'. Another mother said: 'Dad is served first. Dad's portion is first removed after cooking'. Another one declared: 'Fathers are outside they could have found something to eat outside, and child would be fasting at home? Children are served first' (see Table 4 for detailed verbatim responses). Most mothers said children are served first, but the men receive the 'best' part of the meals, and in some households, the men are served first, or their portions are removed before serving the children and other members of the household.

\section{Food taboos and beliefs}

Food taboos and misconceptions about food use contribute to the high levels of undernutrition. In fact, it plays a significant role in determining the diets of pregnant and lactating women, infants and young children. In the community studied, there are food taboos, but it is no longer respected by many. Some families or members of certain religions define some food items as appropriate for consumption and others less so [47]. According to the discussion guide used during focus groups, the following were explored: their understanding of food taboos, food taboos they knew restrictions during pregnancy and breastfeeding (women); foods that they ate especially during pregnancy and lactation for good health of the child, foods young children cannot eat according to cultural beliefs and foods not eaten during illness according to cultural beliefs. Their responses are in Table 5. They held food taboos such as not eating pork or dog meat. One of the mothers said: 'Pork is taboo for Muslims and some families. Others cited dog, cat, catfish, jute sauce with palm oil. There are no explanations, we got it from elders'.

Furthermore, there are dietary restrictions during the period of pregnancy where women avoid nutritious foods for reasons such as avoiding having a big baby, facilitating labour and delivery, or not bearing a child which results in avoidance of certain foods. The study revealed that eggs, cane rat and wild meat were avoided during pregnancy. Long and hard labour was the reason given for avoiding it. They said 'No eggs during pregnancy. We can eat but whole, we couldn't share with someone else. A pregnant woman should not prepare eggs and give to someone. She must cook for herself and when she removes the shell it should not have any hurt otherwise, she should not eat because she might have birth complications'. Another group said, 'When we are pregnant, we do not eat cane rat (giant rats)'. Ekwochi et al. [12] reported similar findings in their study on food taboos and myths in Southeastern Nigeria. Similarly, Gambian women do not eat catfish during pregnancy to prevent giving birth to a dribbling baby [14] Long and difficult child labour was the main reason given for avoiding those foods [12]. While breastfeeding, mothers eat some foods to have more nutritious milk but avoid other foods such as bananas, papayas and mangoes. These dietary restrictions reduce the potential intake of proteins, vitamins and minerals which are essential for growth and development. These nutritional habits also have an impact on the nutritional status of the child, as the child receives all his/her nutrients from the mother, whether the child is still in the womb or already breastfeeding. In rural Ethiopia, pregnant women avoid eating green leafy vegetables, yoghurt, cheese, sugar cane and green pepper as habitual in fear of obstetric complications associated with the delivery of a bigger infant [13]. David et al. have reported in their study on school-going children in Machakos District, Kenya, that cultural beliefs, taboos and attitudes negatively affect food consumption [48]. In another study in the Gambia, it has been proven that taboos, customs and beliefs contribute to malnutrition among the Fula in different ways [14]. A study in Kenya observed that food taboos are delaying the progress in fighting undernutrition because of cultural beliefs [15]. These beliefs are thought to limit the intake of essential nutrients. Furthermore, a study conducted in Papua New Guinea has shown that many foods that are rich sources of protein have been enlisted as taboos for pregnant women. It is believed that because protein helps the body to grow, if 
a woman consumes a lot of protein in her pregnancy, then the baby will grow too big leading to complications during labour [16]. It is now believed that some of the food taboos on restrictions on what women could eat are rooted in the patriarchal philosophy of the past rather than physiological requirements. Health professionals responsible for developing nutrition education materials in areas where taboos are still prevalent must be aware of these. They should further ensure coverage and countering those practices that are likely to harm the pregnant mother or the infant.

\section{Limitations of this study}

The FGDs were conducted in Mina (local language) since most mothers did not understand French. For analysis, the data were first translated to French and then into English. Quality checks of the Mina and English were done by the researcher. However, it is known that the gist of words could have been lost in the progress of transcription and translation.

\section{Conclusion}

The findings revealed that most mothers treated their ill children at home with self-prescribed tablets or herbal tea and only go to the hospital when the condition worsens. Socio-cultural influences were one of the determinants of the decisions that mothers made on child care and feeding practices. Many interventions are focused on the treatment of undernutrition, but it is necessary to raise awareness about the challenges brought by the influence of cultural practices in communities. On the basis of our findings, interventions should be focused on the household dynamics, as cultural norms are a barrier to child care. Educational interventions should be designed to raise awareness of the negative impacts of some socio-cultural practices on the health of the mother and child. It would be beneficial if the authorities organised nutrition education sessions in urban and peri-urban communities to improve the mothers' knowledge on nutrition, food and child care practices based on local dietary practices. Involvement of men, religious and local authorities, as well as older women (grandmothers), would be an asset in adjusting diets all the while still respecting the culture of the environment.

\section{Abbreviations \\ DHS: Demographic Health Survey; FAO: Food and Agriculture Organization; FDG: Focus group discussion; IQ: Intellectual quotient; SDGs: Sustainable Development Goals; WHO: World Health Organization}

\section{Acknowledgements}

We sincerely acknowledge the community of Grand Popo for their hospitality and for spending their precious time with us during the research.

\section{Authors' contributions}

YUAL conceptualised the study, collected and analysed the data and contributed to the development and write up of the manuscript. ABT contributed to the design and development and write up of the manuscript. CA was the co-supervisor for the project and based in Benin, provided oversight and quality control for the data collection and contributed to the development and write up of the manuscript. XM was the main supervisor of the project from conception to the empirical phase and contributed to the design, development and write up of the manuscript. The author(s) read and approved the final manuscript.

\section{Authors' information}

- Yrence Urielle Amoussou Lokossou holds a master's degree in public health nutrition from Stellenbosch University.

- Ayuk Betrand Tambe holds a PhD in health studies, University of South Africa. He is a postdoctoral fellow with the research chair in food environments, nutrition and health at the Stellenbosch University. He also holds a research officer position at the Centre for Food and Nutrition Research at the Institute of Medical Research and Medicinal Plant Studies in Yaoundé, Cameroon. He is also a lecturer at the Catholic University of Central Africa, Yaoundé, Cameroon. He has also been involved with the Catholic Relief Services, an NGO, in Yaoundé, Cameroon. His research interests include nutritional epidemiology, food safety and occupational health safety.

- Colette Azandjèmè is a senior lecturer, Health Promotion Department, Regional Institute of Public Health, University of Abomey-Calavi (Benin). She is a scientist in the Benin Republic, and her research areas of interest are health promotion, nutrition and prevention of diseases, food safety and security and child and maternal nutrition.

- Xikombiso Mbhenyane is a professor, head and research chair in food environments, nutrition and health in the Division of Human Nutrition at the Faculty of Medicine and Health Sciences, Stellenbosch University. She is a C3 NRF-rated scientist in South Africa, and her research areas of interest are indigenous foods, nutrition and prevention of diseases; food and nutrition security; and child and maternal nutrition.

\section{Funding}

The master's student was supported by the AFIMEGQ, and the project was funded through the National Research Foundation (RSA) funding.

Availability of data and materials

The questionnaires and electronic data are available and stored at the Division of Human Nutrition at Stellenbosch University. The data is available upon request from the corresponding author.

\section{Declarations}

Ethics approval and consent to participate

The study protocol was submitted to the Health Research Ethics Committee of the Faculty of Medicine and Health Sciences, Stellenbosch University, and ethics approval was obtained (reference No: S16/10/211).

\section{Consent for publication}

All authors have approved the manuscript.

\section{Competing interests}

The authors declare that they have no competing interests.

\section{Author details}

${ }^{1}$ Division Human Nutrition, Faculty of Medicine and Health Sciences, Stellenbosch University, PO Box 241, Cape Town 8000, South Africa. ${ }^{2}$ Institut Régional de Santé Publique, Université d'Abomey-Calavi, Cotonou, Benin.

Received: 25 September 2019 Accepted: 9 July 2021

Published online: 23 July 2021

\section{References}

1. International Food Policy Research Institute, (IFPRI). 2016. Global Food Policy Report 2016.

2. World Health Organization. 2017. Article [Online]. Available: http://www. who.int/features/qa/malnutrition/en/ [2017, 27 September 2017]. 
3. World Health Organization WHO, United Nations Children's Fund UNICEF World Bank Group2017. Joint Child Malnutrition Estimates. WHO Library Cataloguing-in-Publication Data.

4. WHO/UNICEF. Joint monitoring programme for water supply and sanitation (JMP). Progress on sanitation and drinking-water: 2014 update. New York; Geneva: UNICEF and World Health Organization; 2014

5. Cusick SE, Georgieff MK. The role of nutrition in brain development: the golden opportunity of the "first 1000 days". J Pediatr. 2016;175:16-21. https://doi.org/10.1016/j.jpeds.2016.05.013.

6. CAPO-CHICHI, Y.J. 2006. Monographie de la Commune de Grand-Popo. Cabinet Afrique Conseil. 54p.

7. Jones G, Steketee RW, Black RE, Bhutta ZA, Morris SS. Child survival II: how many child deaths can we prevent this year? Lancet. 362(9377):65-71. https://doi.org/10.1016/S0140-6736(03)13811-1.

8. Kramer M, Kakuma R. Optimal duration of exclusive breastfeeding. Cochrane Database Syst Rev. 2012;8:CD003517. https://doi.org/10.1002/14651858. CD003517.

9. Horta BL, Victora CG. Long-term effects of breastfeeding, vol. 74. Geneva: World Health Organization; 2013.

10. Sankar MJ, Sinha B, Chowdhury R, Bhandari N, Taneja S, Martines J, et al. Optimal breastfeeding practices and infant and child mortality: a systematic review and meta-analysis. Acta Paediatrica. 2015;104(S467):3-13. https://doi. org/10.1111/apa.13147.

11. Ogbo FA, Agho K, Ogeleka P, Woolfenden S, Page A, Eastwood J, et al. Infant feeding practices and diarrhoea in sub-Saharan African countries with high diarrhoea mortality. Plos One. 2017;12(2):1-17. https://doi.org/10.1371/ journal.pone.0171792.

12. Ekwochi U, Osuorah CDI, Ndu IK, Ifediora C, Asinobi IN, Eke CB. Food taboos and myths in South Eastern Nigeria: the belief and practice of mothers in the region. J Ethnobiol Ethnomed. 2016;12(1):7. https://doi.org/10.1186/s13 002-016-0079-x.

13. Zerfu TA, Umeta M, Baye K. Dietary habits, food taboos, and perceptions towards weight gain during pregnancy in Arsi, rural central Ethiopia: a qualitative cross-sectional study. J Health Popul Nutr. 2016;35(22):1-7. https://doi.org/10.1186/s41043-016-0059-8.

14. Pérez GM, García AP. Nutritional taboos among the Fullas in Upper River Region, The Gambia. J Anthropol. 2013;2013:1-9. https://doi.org/10.1155/2 013/873612.

15. Abubakar A, Uriyo J, Msuya SE, Swai M, Stray-Pedersen B. Prevalence and risk factors for poor nutritional status among children in the Kilimanjaro Region of Tanzania. Int J Environ Res Public Health. 2012;9(10):3506-18. https://doi.org/10.3390/ijerph9103506.

16. Kuzma J, Paofa D, Kaugla N, Catherina T, Samiak S, Kumei E. Food taboos and traditional customs among pregnant women in Papua New Guinea: missed opportunity for education in antenatal clinics. Contemp PNG Stud. 2013;19:1.

17. Amoussou Lokossou YU, Azandjèmè $C$, Ayuk BT, Mbhenyane $X$. The presence of the double burden of malnutrition in children and their mothers in Grand-Popo, Benin. Nutr Health. 2020;27(1):89-96.

18. Creswell JW, Poth CN. Qualitative inquiry \& research design: choosing among five approaches. 4th ed. Thousand Oaks: SAGE Publications; 2013.

19. Institut National de la Statistique et de l'Analyse Economique, (INSAE). RGPH4: Que retenir des effectifs de population en 2013; 2015. p. 33.

20. Krueger, R.A., Casey, M.A. 015. Focus groups: a practical guide for applied research. Los Angeles, CA: Safe

21. Barbour R. Underpinnings of focus group research. Doing focus groups. London: SAGE Publications; 2007. https://doi.org/10.4135/9781849208956.

22. Hennink MM, Kaiser BN, Weber MB. What influences saturation? Estimating sample sizes in focus group research. Qual Health Res. 2019;29(10):1483-96. https://doi.org/10.1177/1049732318821692.

23. Cunha DB, de Almeida RMVR, Sichieri R, Pereira RA. Association of dietary patterns with BMI and waist circumference in a low-income neighbourhood in Brazil. Br J Nutr. 2010;104(6):908-13. https://doi.org/10.1017/S000711451 0001479 .

24. Glover-Amengor M, Agbemafle I, Hagan LL, Mboom FP, Gamor G, Larbi A, et al. Nutritional status of children 0-59 months in selected intervention communities in northern Ghana from the Africa RISING project in 2012. BMC Arch Public Health. 2016;74(12):12. https://doi.org/10.1186/s13690-0160124-1.

25. Creswell JW. Research design: qualitative, quantitative, and mixed methods Approaches. 4th ed: SAGE Publications, Inc; 2014.
26. Mengistu K, Alemu K, Destaw B. Prevalence of malnutrition and associated factors among children aged 6-59 months at Hidabu Abote District, North Shewa, Oromia regional state. J Nutr Disord Ther. 2013;3(03):1-15. https:// doi.org/10.4172/2161-0509.T1-001.

27. Demissie S. Magnitude and factors associated with malnutrition in children 6-59 months of age in pastoral community of Dollo Ado District, Somali Region, Ethiopia. Sci J Public Health. 2013;1:175. https://doi.org/10.11648/j. sjph.20130104.12.

28. Ma'alin A, Birhanu D, Melaku S, Tolossa D, Mohammed Y, Gebremicheal K. Magnitude and factors associated with malnutrition in children 6-59 months of age in Shinille Woreda, Ethiopian Somali regional state: a crosssectional study. BMC Nutr. 2016;2(1):44. https://doi.org/10.1186/s40795-0160079-1.

29. Wood KM, Qureshi K. Facilitators and barriers for successful breastfeeding among migrant Chuukese mothers on Guam. SAGE Open Nurs. 2017;3: 2377960816688909.

30. World Health Organisation. Infant and young child feeding. Fact Sheet N. 2010;342.

31. Diagne-Guèye NR, Diack-Mbaye A, Dramé M, Diagne I, Fall AL, Camara B, et al. Knowledge and practices of Senegalese mothers living in rural areas or suburban on the nutrition of their children, from birth to six months of age. J Pediatr Childcare. 2011;24(4):161-6.

32. Seonandan $\mathrm{P}, \mathrm{Mckerrow} \mathrm{NH}$. A review of infant and young child feeding practice in hospital and the home in KwaZulu-Natal midlands. South Afr J Clin Nutr. 2016;29(3):111-5. https://doi.org/10.1080/16070658.2016.1198567.

33. Goosen C, McLachlan M, Schübl C. Infant feeding practices during the first 6 months of life in a low-income area of the Western Cape province. South Afr J Child Health. 2014;8(2):50-4. https://doi.org/10.7196/SAJCH.675.

34. Muhimbula HS, Issa-Zacharia A, Kinabo J. Formulation and sensory evaluation of complementary foods from local, cheap and readily available cereals and legumes in Iringa, Tanzania. Afr J Food Sci. 2011;5:26-31.

35. Budree S, Zar HJ, Goddard E, Myer L. Infant feeding practices in a South African birth cohort-a longitudinal study. Matern Child Nutr. 2016;13(3):19. https://doi.org/10.1111/mcn.12371.

36. Mitchodigni I, Hounkpatin W, Ntandou-Bouzitou G, Termote C, Kennedy G, Hounhouigan D. Complementary feeding practices of children aged 6-23 months in rural area, Southern-Benin: challenges and opportunities. Int J Trop Dis Health. 2017;24(2):1-12. https://doi.org/10.9734/IJTDH/2017/33877.

37. Tshite FN, Mulamba VT. Mise au point d ' une farine précuite à base de maïs (Zea mays) et de soja (Glycine max) par la méthode traditionnelle Formulation of precooked flour basic on maize (Zea mays) and soya beans (Glycine max) by traditional method. Int J Biol Chem Sci. 2015;9(6):2608-22.

38. Zeba AN, Delisle HF, Renier G. Dietary patterns and physical inactivity, two contributing factors to the double burden of malnutrition among adults in Burkina Faso, West Africa. J Nutr Sci. 2014;3(e50):e50. https://doi.org/10.101 7/jns.2014.11.

39. Frank LK, Kröger J, Schulze MB, Bedu-Addo G, Mockenhaupt FP, Danquah I. Dietary patterns in urban Ghana and risk of type 2 diabetes. Br J Nutr. 2014; 112(1):89-98. https://doi.org/10.1017/S000711451400052X.

40. Dror DK, Allen LH. The importance of milk and other animal-source foods for children in low-income countries. Food Nutr Bull. 2011;32(3):227-43. https://doi.org/10.1177/156482651103200307.

41. Nago ES, Lachat CK, Huybregts L, Roberfroid D, Dossa RA, Kolsteren PW. Food, energy and macronutrient contribution of out-of-home foods in school-going adolescents in Cotonou, Benin. Br J Nutr. 2010;103(2):281-8. https://doi.org/10.1017/S0007114509991668.

42. Layade AA, Adeoye IB. Fruit and vegetable consumption among students of tertiary institutions in Oyo state. Russian J Agric Socio-Econ Sci. 2014;30(6):3-8.

43. Bosu WK. An overview of the nutrition transition in West Africa: implications for non-communicable diseases. Proc Nutr Soc. 2014;74(4):466-77. https:// doi.org/10.1017/S0029665114001669.

44. Kimani-Murage EW, Wekesah F, Kyobutungi C, Wanjohi M, Ezeh AC, Musoke $\mathrm{RN}$, et al. Factors affecting actualization of the WHO breastfeeding recommendations in urban poor settings in Nairobi Kenya. Matern Child Nutr. 2014;11(3):283-414. https://doi.org/10.1111/mcn.12161.

45. Kamau-Thuita F, Omwega AM, Muita JW. Childcare practices and nutritional status of children aged 0-2 years in Thika, Kenya. East Afr Med J. 2002;79(10): 524-9. https://doi.org/10.4314/eamj.v79i10.8814.

46. Akerele D. Intra-household food distribution patterns and calorie inadequacy in South-Western Nigeria. Int J Consumer Stud. 2011;35(5):54551. https://doi.org/10.1111/j.1470-6431.2010.00981.x. 
47. Denning, G. and Fanzo, J. 2016. Ten forces shaping the global food system. In Kraemer K, Cordaro JB, Fanzo J, Gibney M, Kennedy E, Labrique A, Steffen J, Eggersdorfer M. 1 Ten forces shaping the global food system. In Good nutrition: perspectives for the 21st century 2016 (pp. 19-30). Karger Publishers.

48. David MD, Kimiywe J, Waudo J. Nutritional knowledge, attitude and practices and nutritional status of school-going children in Machakos District, Kenya. In International Conference on Nutrition and Food Sciences, IPCBEE 2012 (Vol. 39).

\section{Publisher's Note}

Springer Nature remains neutral with regard to jurisdictional claims in published maps and institutional affiliations.

Ready to submit your research? Choose BMC and benefit from:

- fast, convenient online submission

- thorough peer review by experienced researchers in your field

- rapid publication on acceptance

- support for research data, including large and complex data types

- gold Open Access which fosters wider collaboration and increased citations

- maximum visibility for your research: over $100 \mathrm{M}$ website views per year

At $\mathrm{BMC}$, research is always in progress.

Learn more biomedcentral.com/submissions 